\title{
APPLICATION OF ELECTRONIC MODULE TEACHING MATERIALS TO IMPROVE STUDENT LEARNING OUTCOMES IN RHYTHMIC GYMNASTICS SUBJECT
}

\author{
Oktariyana $^{1 *}$, Oktariyani $^{2}$ \\ ${ }^{12}$ Physical Education for Health and Recreation, Faculty of Social and Humanities, Universitas \\ Nahdlatul Ulama Lampung, Lampung, Indonesia
}

\section{Info Artikel}

\section{Article History :}

Received September 2020

Revised September 2020

Accepted September 2020

Available online September 2020

Keywords:

Teaching Materials, Electronic Module, Rhythmic Gymnastics

\begin{abstract}
The learning process that is currently taking place in the rhythmic gymnastics course in the Health and Recreation Physical Education study program at the University of Nahdlatul Ulama Lampung is still using the printed module. This is still considered ineffective and inefficient, which causes student learning outcomes in low rhythm gymnastics courses. This study aims to determine the increase in student learning outcomes between before and after being given an electronic module in rhythmic gymnastics courses. The method used in this study was one group pre-test post-test design. In this study, a pre-test and post-test were conducted to determine the increase in student learning outcomes. The increase in student learning outcomes is expressed by the N-Gain score. The results showed that the applied electronic module teaching materials could improve student learning outcomes in rhythmic gymnastics courses. Where the average N-Gain score was $56.75 \%$ with the category quite effective. Thus the application of electronic module teaching materials can improve student learning outcomes in rhythmic gymnastics courses.
\end{abstract}

\begin{tabular}{llr}
\hline Corresponding address & $:$ Mataram Marga, Sukadana, Kabupaten Lampung & ISSN 2685-6514 (online) \\
& Timur, Lampung & ISSN 2477-331X (print) \\
Email & : oktariyana07@gmail.com & DOI : 10.33369/jk.v4i2.12529
\end{tabular}




\section{INTRODUCTION}

The Rhythmic Gymnastics course is one of the movement skills courses in the Health and Recreation Physical Education Study Program, Faculty of Social and Humanities, University of Nahdlatul Ulama Lampung. The learning objectives of this course are that students will be able to understand the basic concepts of rhythmic gymnastics, master various patterns of rhythmic gymnastics steps, understand and practice rhythmic gymnastics, master rhythmic activities with various rhythms: mars, waltz, chacha, create rhythmic motion sequences with rhythms. which he chooses, has a respectful and creative attitude. (Heater, 2003)explains that rhythmic gymnastics is a sport that brings pleasure and joy in moving and using musical rhythms.

In learning rhythmic gymnastics, students are required to be able to learn independently. This is by the opinion (Suprijanto, 2008) which explains that the learning process takes place in the form of self-direction to solve problems. This means that to facilitate students to learn independently, the task of educators is to provide a pleasant learning atmosphere. Educators must find ways to make learning fun during the learning process. One way to make learning fun is to use fun teaching materials, namely teaching materials that can make students feel interested and happy to learn the teaching materials.

Teaching materials are materials or lecture materials that are arranged systematically, which are used by lecturers and students in the learning process (Panen et al., 2001). Teaching materials can be made in various forms according to the needs and characteristics of the teaching materials to be presented (Depdiknas, 2008). With the existence of good and interesting teaching materials, the expected goal can be achieved, namely improving the learning outcomes of students, in this case, students. Learning outcomes are abilities that students have after receiving their learning experiences (Sudjana, 2011).

A learning process to increase the achievement of learning outcomes needs to be supported by appropriate teaching materials. This is because the time to face the class is very limited when compared to the volume of material that must be completed. Therefore we need a teaching material that can activate students in learning. Among the teaching materials that make it possible to improve student learning outcomes by prioritizing student active independence is the electronic module.

Learning modules are learning resources other than teachers that are systematically designed by experts in certain fields of study or the teaching profession according to design principles to increase effectiveness, efficiency, and increasing student interest in continuing to learn (Wiyogo, 2013). Another opinion explains that modules are a way of organizing subject matter that takes into account the function of education (Santyasa, 2009). The main purpose of teaching materials in the form of modules is that readers can absorb the material or teaching materials independently (Daryanto, 2013). There are several characteristics of the module including 1) Self Instructional; 2) Self Contained; 3) Stand Alone (stand-alone); 4) Adaptive; and 5) User Friendly (Departemen Pendidikan Nasional, 2008). A module can be said to be good and interesting if it has these characteristics.

The learning process that is currently taking place in the rhythmic gymnastics course in the Physical Education Health and Recreation study 
program at the University of Nahdlatul Ulama Lampung is still using the printed module. This is still considered less effective and efficient, which causes student learning outcomes in low rhythm gymnastics courses. Learning outcomes are abilities that students have after receiving their learning experiences (Sudjana, 2011).

The development of science, technology, and information brings changes and new paradigms in learning materials and learning methods (Darmawan, 2012). The very rapid development of technology produces new things, both technology in general and technological developments in the world of education. Technological developments in the world of education, for example, develop teaching material products in the form of e-modules. E-modules are documents or articles in an electronic format that have many benefits for learning media. Also, e-module teaching materials are one of the teaching materials whose publishing process in digital form consists of text, images, or a combination of both.

The advantages of teaching materials in the form of electronic modules have been proven based on several previous research results, namely research from (Suyoso \& Nurohman, 2014) which produced a product in the form of a web-based electronic module as a physics learning medium and was able to improve student learning achievement. And research from (Ramdhani et al., 2020) resulted in research that the electronic module product of chemical bonding material can improve student learning outcomes. The use of teaching materials in the form of electronic modules is not only beneficial because of its interactivity and accessibility but can also increase students' active independence in learning.

\section{METHODS}

This research was conducted at the University of Nahdlatul Ulama Lampung, Health and Recreation Physical Education Study Program. The approach used in this study is a quantitative approach to compare the ability of student learning outcomes in rhythmic gymnastics courses through electronic modules in rhythmic gymnastics courses. This type of research was used in this study using the experimental method one group pre-test post test design. Sampling was done randomly. The research sample was students in semester 3 (three) totaling 40 students consisting of 2 classes, research subjects were each given a pretest and posttest. The pretest and post-test score data were obtained from the questions given to students, in this case, the students.

After the data was collected, the researcher then conducted a normality test. (Widhiarso, 2017) explains that the normality test is a test to measure whether our data has a normal distribution so that it can be used in parametric statistics (inferential statistics). After the data is categorized as normal, then the t-test is carried out, namely the paired sample ttest. The paired-test is a parametric difference test on two paired data (Hidayat, 2014). And then calculate the $\mathrm{N}$-Gain to determine the effectiveness of the application of electronic module teaching materials for rhythmic gymnastics courses. The formula $(\mathrm{N}$ Gain) according to (Archambault, 2008) is as follows: 
$N$ Gain $=\frac{\text { Skor Posttest }- \text { Skor Pretest }}{\text { Skor Ideal }- \text { Skor Pretest }}$

The criteria for the $\mathrm{N}$-gain score can be determined based on the $\mathrm{N}$-gain value or in the form of a\% (percent). namely as in the following table:

Table 1. Distribution of Score Gain

\begin{tabular}{cc}
\hline Nilai N-gain & Kategori \\
\hline $\mathrm{g}>0,7$ & Tinggi \\
\hline $0,3 \leq \mathrm{g} \leq 0,7$ & Sedang \\
\hline $\mathrm{g}<0,3$ & Rendah \\
\hline
\end{tabular}

For the division of the $\mathrm{N}$-gain category in the form of $\%$ (percent), please refer to the following table:

Table 2. Category of Interpretation of N-

\begin{tabular}{cc}
\multicolumn{2}{c}{ Gain Effectiveness } \\
\hline Nilai N-gain & interpretation \\
\hline$<40$ & Tidak Efektif \\
\hline $40-55$ & Kurang Efektif \\
\hline $56-75$ & Cukup Efektif \\
\hline$>76$ & Efektif \\
\hline
\end{tabular}

\section{RESULTS AND DISCUSSION}

To find out the effectiveness of the application of electronic module products for rhythmic gymnastics courses that were tested on students. So there is data that must be collected, namely data on the ability of student learning outcomes in rhythmic gymnastics courses. This data collection was carried out after the large group test. Collecting the effectiveness test data using the t-test with the help of SPSS software. During the implementation of field trials, students are given a pre-test and post-test. Giving pretest and post-test aims to determine the difference in the mean results of students' learning ability in rhythm gymnastics subject before and after being given the module. The following is the data obtained from the pre-test and post-test results of students' learning abilities in the rhythmic gymnastics subject:

Table 3. Acquisition of Pre-Test and Post-Test Values of Student Learning Ability Results

\begin{tabular}{ccc|ccc}
\hline Respondent & Pretest & Posttest & Respondent & Pretest & Posttest \\
\hline $\mathrm{X} 1$ & 65 & 75 & $\mathrm{X} 21$ & 65 & 80 \\
\hline $\mathrm{X} 2$ & 75 & 80 & $\mathrm{X} 22$ & 60 & 85 \\
\hline $\mathrm{X} 3$ & 65 & 78 & $\mathrm{X} 23$ & 80 & 85 \\
\hline $\mathrm{X} 4$ & 75 & 80 & $\mathrm{X} 24$ & 76 & 75 \\
\hline $\mathrm{X} 5$ & 75 & 85 & $\mathrm{X} 25$ & 77 & 80 \\
\hline $\mathrm{X} 6$ & 70 & 85 & $\mathrm{X} 26$ & 68 & 75 \\
\hline $\mathrm{X} 7$ & 73 & 75 & $\mathrm{X} 27$ & 76 & 90 \\
\hline $\mathrm{X} 8$ & 72 & 80 & $\mathrm{X} 28$ & 60 & 80 \\
\hline $\mathrm{X} 9$ & 65 & 75 & $\mathrm{X} 29$ & 67 & 85 \\
\hline $\mathrm{X} 10$ & 70 & 90 & $\mathrm{X} 30$ & 60 & 84 \\
\hline $\mathrm{X} 11$ & 70 & 80 & $\mathrm{X} 31$ & 70 & 82 \\
\hline $\mathrm{X} 12$ & 65 & 85 & $\mathrm{X} 32$ & 60 & 79 \\
\hline $\mathrm{X} 13$ & 80 & 84 & $\mathrm{X} 33$ & 80 & 89 \\
\hline $\mathrm{X} 14$ & 75 & 82 & $\mathrm{X} 34$ & 76 & 90 \\
\hline $\mathrm{X} 15$ & 70 & 79 & $\mathrm{X} 35$ & 77 & 88 \\
\hline $\mathrm{X} 16$ & 75 & 89 & $\mathrm{X} 36$ & 60 & 75 \\
\hline $\mathrm{X} 17$ & 80 & 90 & $\mathrm{X} 37$ & 70 & 78 \\
\hline $\mathrm{X} 18$ & 73 & 75 & $\mathrm{X} 38$ & 65 & 65 \\
\hline $\mathrm{X} 19$ & 72 & 80 & $\mathrm{X} 39$ & 67 & 80 \\
\hline $\mathrm{X} 20$ & 65 & 78 & $\mathrm{X} 40$ & 75 & 90 \\
\hline & & & & & \\
\hline
\end{tabular}

From the student learning outcomes data above, the data normality test was carried out, namely the Kolmogorov-Smirnov test and the Shapiro-Wilk test using SPSS, before the t-test was carried out. The following are the results of the data normality test with SPSS.

Tabel 4. Tests of Normality students Learning outcome data

\begin{tabular}{lcccccc}
\hline & \multicolumn{3}{c}{ Kolmogorov-Smirnov $^{\mathrm{a}}$} & \multicolumn{3}{c}{ Shapiro-Wilk } \\
\hline & Statistic & df & Sig. & Statistic & Df & Sig. \\
\hline Pre-test & .144 & 40 & .035 & .937 & 40 & .027 \\
\hline Post-test & .155 & 40 & .017 & .932 & 40 & .018 \\
\hline
\end{tabular}

Based on the results of the output above, it is known that the KolmogorovSmirnov and Shapiro-Wilk significance 
values for pre-test and post-test data are> 0.05 , so it can be concluded that the data is normally distributed. Then the next step is the t-test. The following are the results of the t-test pre-test and post-test values.

Table 5. Paired Samples Statistics Std.

Mean N Deviation Std. Error Mean

\begin{tabular}{|c|c|c|c|}
\hline \multicolumn{2}{|r|}{ Pretest } & 70.4840 & 6.139 \\
\hline
\end{tabular}

\begin{tabular}{llll}
\hline Posttest & 81.5040 & 5.639 & .892 \\
\hline
\end{tabular}

Based on the output results in the Paired Samples Statistics above, it can be seen that the average student learning test results in the rhythmic gymnastics subject after being given an electronic module are $=81.50$ and a standard deviation of $=5.63$ while the average results of the students' learning tests in the rhythm gymnastics course before being given an electronic module of $=70.48$ with a standard deviation of $=6.13$. This means that descriptively the student learning outcomes of the rhythmic gymnastics subject were given the electronic module are better.

Table 6. Paired Samples Test

\begin{tabular}{|c|c|c|c|c|c|c|c|}
\hline & \multicolumn{4}{|c|}{ Paired Differences } & \multirow[b]{3}{*}{$\mathrm{t}$} & \multirow[b]{3}{*}{ df } & \multirow{3}{*}{$\begin{array}{l}\text { Sig. (2. } \\
\text { tailed) }\end{array}$} \\
\hline & \multirow{2}{*}{ Mean } & $\begin{array}{c}\text { Std. Std. } \\
\text { Deviatio Error }\end{array}$ & $\begin{array}{r}95 \\
\text { Confic } \\
\text { Interval } \\
\text { Differ } \\
\end{array}$ & $\begin{array}{l}\% \\
\text { dence } \\
l \text { of the } \\
\text { rence } \\
\end{array}$ & & & \\
\hline & & $\mathrm{n} \quad$ Mean & Lower & Upper & & & \\
\hline $\begin{array}{r}\text { Pair } 1 \text { Prestes - } \\
\text { Posttest }\end{array}$ & -11.025 & $=6.294 .995-$ & -13.038 & -9.012 & -11.078 & 39 & .000 \\
\hline
\end{tabular}

In the results of the Paired Samples Test output data on the results of student learning abilities above, the value of $\mathrm{t}=11.07$ and the value of Sig. (2tailed) or p-value $=0.000<0.05$ or Ho is rejected. So thus the proposed hypothesis is tested by the data, so it is concluded that there is a significant increase in the results of the students' learning ability test in rhythmic gymnastics subject after being given an electronic module. Furthermore, to determine the effectiveness of the application of the electronic module, it can be tested by calculating the N-Gain Score. The gain score is the difference between the posttest and pre-test scores.

Table 7. Descriptives Hasil Perhitungan Uji N-Gain Score

Std. Statistic Error

\begin{tabular}{|c|c|c|c|}
\hline \multirow[t]{13}{*}{$\begin{array}{l}\text { NGain } \\
\text { Persen }\end{array}$} & Mean & 56.7559 & $\begin{array}{r}4912 \\
3\end{array}$ \\
\hline & $\begin{array}{l}95 \% \text { Confidence Low } \\
\text { Interval for Mean Boun }\end{array}$ & 47.6715 & \\
\hline & $\begin{array}{l}\text { Uppe } \\
\text { Boun }\end{array}$ & 65.8403 & \\
\hline & 5\% Trimmed Mean & 57.7049 & \\
\hline & Median & 52.0000 & \\
\hline & Variance & 806.846 & \\
\hline & Std. Deviation & $\begin{array}{r}2.84050 \mathrm{E} \\
1\end{array}$ & \\
\hline & Minimum & -7.14 & \\
\hline & Maximum & 100.00 & \\
\hline & Range & 107.14 & \\
\hline & Interquartile Range & 40.00 & \\
\hline & Skewness & -.186 & .374 \\
\hline & Kurtosis & -.468 & .733 \\
\hline
\end{tabular}

Based on the output table descriptions of the $\mathrm{N}$-gain score in the table above, it shows that the average $\mathrm{N}$ gain score is $56.75 \%$, including in the "quite effective" category, with a minimum $\mathrm{N}$-gain score of $-7.14 \%$ and $\mathrm{N}$ the maximum gain score is $100 \%$.

\section{CONCLUSION}

Based on the results of the calculation of the $\mathrm{N}$-gain score, the $\mathrm{N}$ gain score is $56.75 \%$, including in the "quite effective" category, with a minimum $\mathrm{N}$-gain score of $-7.14 \%$ and a maximum $\mathrm{N}$-gain score of $100 \%$. So it can be concluded that the application of the electronic module in the rhythmic gymnastics course is "quite effective" to improve the learning ability of students in the rhythmic gymnastics course. 
The researcher's suggestion is to be able to develop this electronic module on a wider range of material and not just one material, by better being able to disseminate and apply it to several different universities not only to different classes in the same school

\section{REFERENCES}

Akmal, A., Sugihartono, T., \& Ilahi, B. R. (2018). ANALISIS MUATAN MATERI SENAM PADA BAHAN AJAR PJOK SEKOLAH DASAR NEGERI DI KOTA BENGKULU. Kinestetik: Jurnal Ilmiah Pendidikan Jasmani, 2(1), 11-15.

Archambault, J. (2008). The Effect of Developing Kinematics Concepts Graphically Prior to Introducing Algebraic Problem Solving Techniques. Action Research Required for the Master of Natural Science Degree with Concentration in Physics. Arizona State University.

Darmawan, D. (2012). Inovasi Pendidikan: Pendekatan Praktik Teknologi Multimedia dan Pembelajaran Online. PT Remaja Rosdakarya.

Daryanto. (2013). Menyusun Modul. Gava Media.

Departemen Pendidikan Nasional. (2008). Penulisan Modul. Departemen Pendidikan Nasional.

Depdiknas. (2008). Panduan Pegembangan Bahan Ajar. Direktorat Jenderal Manajemen Pendidikan Dasar dan Menengah Direktorat Pembinaan Sekolah Menengah Atas.

Heater, P. C. (2003). Teaching Rhytmic Gymnastics A Developmentally Appropriate Approach. Human Kinetics.

Hidayat, A. (2014). Tutorial Independen T Test dengan SPSS. Https://Www.Statistikian.Com. https://www.statistikian.com/2014/04/i ndependen-t-test-dengan-spss.html

Panen, Paulina, \& Purwanto. (2001). Penulisan Bahan Ajar. PAU-PPAI, Universitas Terbuka.

Ramdhani, E. P., Khoirunnisa, F., \& Siregar,
N. A. N. (2020). Efektifitas Modul Elektronik Terintegrasi Multiple Persentation pada Materi Ikatan Kimia. Journal of Research and Technology, 6(1).

Santyasa, I. (2009). Teori Pengembangan Modul. Universitas Pendidikan Ganesha.Sudjana, N. (2011). Penilaian Hasil Proses Belajar Mengajar. PT Remaja Rosdakarya.

Suprijanto. (2008). Pendidikan Orang Dewasa; dari Teori Hingga Aplikasi. Bumi Aksara.

Suyoso, \& Nurohman, S. (2014). Pengembangan Modul Elektronik Berbasis WEB Sebagai Media Pembelajaran Fisika. Jurnal Kependidikan, 44(1), 73-82.

Widhiarso. (2017). Uji Normalitas. Widhiarso.Staff.Ugm.Ac.Id.

http://widhiarso.staff.ugm.ac.id/files/Uj i Normalitas.pdf

Wiyogo, W. D. (2013). Media Pembelajaran. Wineka Media. 